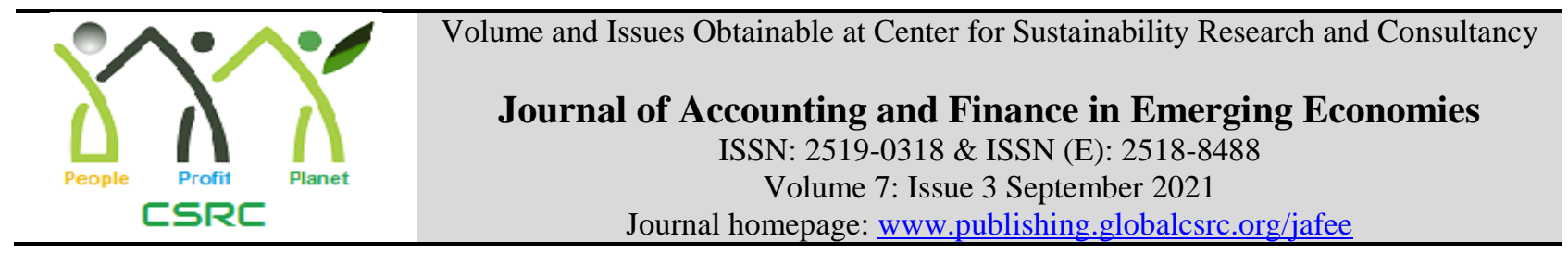

\title{
Employee's Performance as a Consequence of Effective Communication and Working Environment: The Moderating Role of Organizational Learning Culture
}

*Muhammad Adnan, National College of Business Administration and Economics (NCBA\&E) Lahore, Multan Sub-campus, Pakistan

*Corresponding author's email: dr.adnanmalik1989@gmail.com

\begin{tabular}{l}
\hline ARTICLE DETAILS \\
\hline History \\
Revised format: Aug 2021 \\
Available Online: Sep 2021 \\
\hline Keywords \\
Effective communication, \\
Work Environment, \\
Employee's Performance, \\
Organizational Learning \\
Culture, FMCG sector. \\
\end{tabular}

JEL Classification MO,M1

\begin{abstract}
Purpose: FMCG (Fast Moving Consumer Goods) sector has a significant role in the economic development of Pakistan. According to Pakistan Bureau of Statistics, the retail sector contributes $18.6 \%$ to the GDP of Pakistan. This sector can use effective communication with a learning work environment as a tool to increase their productivity and at the same time can build customer relations. This is because communication is an essential element used to deal with customers and employees. Whereas, at the same time comfortable work environment is helpful to boost the performance of this sector. The present study aims to examine the influence of effective communication and working environment on employee's performance with the moderating role of organizational learning culture in FMCG sector of South Punjab Region.

Design/Methodology/Approach: For the said purpose structured questionnaires were developed by using online google forms for collecting data. The sample population was selected from the FMCG sector of Pakistan. Then the collected data was analyzed by using regression analysis and Pearson Correlation via SPSS whilst Structural Equation Modeling (SEM) via Smart PLS.
\end{abstract}

Findings: The results indicates that effective communication and work environment has a significant influence on employee's performance and organizational learning culture plays a moderating role between effective communication and work environment.

Implications/Value: This research has used FMCG sector specifically to examine the impact of effective communication hence, further research can be done by using other sectors i.e., Education, Agriculture, IT etc. In addition to that this study is based on the impact of effective communication and working environment on the employee's performance through the moderating role of organizational culture further research can be made on the ways or methods improve working conditions of this sector.

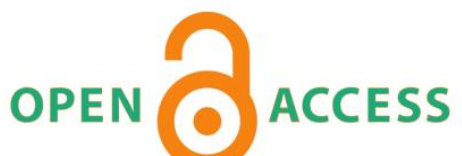

(C) 2021, The authors, under a Creative Commons AttributionNonCommercial 4.0 
Recommended citation: Adnan, M. (2021). Employee's Performance as a Consequence of Effective Communication and Working Environment: The Moderating Role of Organizational Learning Culture. Journal of Accounting and Finance in Emerging Economies, 7 (3), 573-586.

\section{Introduction}

\section{Background}

This study has been conducted to highlight the importance of effective communication and work environment in order to improve the performance of employees. According to Alvesson \& Karreman, 2016, many external as well as internal factors are important for the success of a FastMoving Consumer Goods (FMCG) sector. But human resource is considered to be the most important internal factor except all other factors which helps an organization to work efficiently and effectively (Brewster, 2017). The quality of work, investment and human resource, gives a competitive edge to FMCG sector (Obeidat et al., 2018). In order to retain valuable human resource of an organization it is important to ensure their commitment by providing them learning environment and by communicating effectively (Yousef, 2017).

Work environment is known as the working condition in an organization (Deem, Barnes, Segal \& Preziosi, 2000). This can be physical (lights, furniture, and provision of facilities) or social (relations, motivation, security, effective communication). The provision of healthy physical and social environment can enhance the productivity of employees. Poor working environment, poor communication and physical environment makes employees dissatisfied and unmotivated which had an impact on the performance of an organization.

Communication is simply defined as a process of sending or receiving messages verbally and non-verbally. Effective communication is another important factor which is used to increase performance of employees by building proper coordination between employee and employer. Effective communication helps to increase the performance of an organization, improve employee's coordination, productivity and ultimately helps to increase the performance of a particular sector. Managers must have the skills to understand verbal and non-verbal messages in order to maintain effective communication. Communication is used in business for the purpose of transmitting and receiving information. It also helps in coordinating employee and to build teamwork which increase performance of an organization. Effective communication helps to build confidence level of employees whereas weak communication losses the confidence of employees. Therefore, effective communication has an impact on the performance of employees. Many researches has been conducted to highlight the role of organizational culture in the development of an organization (Hofstede, 1980; Ouchi, 1981; Hofstede \& Bond, 1988; Kotter and Heskett, 1992; Magee, 2002). Human resource is an expensive asset therefore it is important to retain employees in today's competitive world. The working environment has a positive as well as negative effect on employee's performance. In this regards work environment can be used as an instrument to ensure long term commitment to employees. According to Ritchie (2000) organizational culture can be used as a motivational tool to enhance the performance of employees (Ritchie, 2000).

There is a direct link between the performance of employees, effective communication and the work environment. Such environment helps to motivate an employee in order to generate maximum output. Healthy work environment also helps to make an employee mentally healthy and in work-life balance (Chandrasekar, 2011). In addition to that work environment helps to reduce absentees and boost the performance of employees (Boles et al. 2004).

\section{Significance of the Study}

This research has been based on FMCG sector of South Punjab region in Pakistan. Consumers 
use these goods on daily basis and communicate with employees. Such goods include salt, soap, cooking oil etc. The demand of FMCG has increasing day by day in Pakistan. The middle class of Pakistan is increasing and therefore resulting in the increasing sale of FMCG consumer products (Haq, 2018).

The results of this study will help the FMCG sector of south Punjab to improve their organizational culture by changing current practices and adopting new ones. This will also help the scholars to further study the influence of effective communication and work environment in a broader sense. It will make employees aware about the influence of effective communication and work environment in their work performance and how they can increase their performance by maintaining a learning environment and by communication effectively with each other.

\section{Statement of the Research Problem}

There is a need to highlight the influence of effective communication and work environment on employee's performance. According to Noble (2009) there is a need to maintain learning environment in order to ensure employees commitment towards an organization.

\section{Literature Review \\ Employee Performance}

Employee performance is the efficiency of an employee to generate maximum output from the given input and resources. There are many factors that affect employee's performance, some of them are; employees' honesty, level of satisfaction and commitment towards an institution. (Dyrbye et al., 2019). As per Afshan et al. (2012) the performance of employee performance is a specific task performed in an organization by the efforts of an employee. Such can be measured by the stated accuracy, completeness, cost and speed or measured against identified criteria. There are many indicators used by the company to measure performance which enhances the performance of an institution. The effectiveness, quality and efficiency of work can be used as indicators to measure performance (Ahuja, 2006).

Wood and Sangster (2002) and Nasaji (2013), recommends that employee's performance can be determine by the ability of an institution to produce maximum output from the available input. The efficiency is the ability of an employee to achieve maximum result from minimum objectives in order to increase productivity of an organization (Stoner, 1996). Whereas the ratio of input over output in terms of results is known as productivity (Stoner et al., 1995; Lipsey, 1989).

According to Hawthorne studies, satisfied workers are more likely to have better employment returns than others who are dissatisfied with their job (Pieper et al., 2019).

\section{Effective Communication and Employee's Performance}

According to Otoo, F. (2016), it is important for managers to understand different aspects of communication and their impact on employee performance. In addition to knowledge, effective communication must also be considered an important element to enhance the performance of employees and to increase long run productivity. Effective communication can be used as a valuable tool by the employees in order to fulfill their job requirements (Odine, M. 2015). For this, managers must enable free flow of communication in an organization in order to increase performance. According to Jiang, et al. (2020) effective communication can be used as a bridge between management and employees to increase the performance. Because this will help employees to perform in the best interest of an organization simultaneously helps management to effectively monitor the performance of that employee. In order to achieve objectives of an organization, it is necessary to enable effective flow of information Otoo, F. (2016).

H1: Positive relationship exists between effective communication and employee's performance. 


\section{Work Environment}

Work environment is known as the working conditions in which an employee work. Smrita et al. (2010) states that a good working environment has an effect on the level of motivation of employees. According to Opperman (2002) work environment is a composition of three factors or environments: human environment, organizational and the technical environment. Technical environment includes equipment, furniture, temperature, physical environment etc. It enables employees to perform their duties and responsibilities. Human environment includes team, coworkers, coordination issues, management with whom an employee has to work. Such environment helps to share knowledge and information informally in an organization in order to enhance mutual coordination and increasing productivity. The ability to share knowledge in an organization depends upon the work environment of that organization (Brenner (2004). At last, organizational environment is the values, norms, beliefs and systems that is under control of management. Such environment by allowing free flow of effective communication can be used as a tool to motivate employees for producing better results. In the views of Mokaya et al. (2013) working environment plays an important role in order to increase job satisfaction of employees.

In order to develop good working environment, it is important to have good leadership, management, coordination, effective communication, learning culture and transparency in an organization which will leads an organization towards high productivity. Goudswaard (2012).

\section{H2: Positive relationship exists between work environment and employee's performance}

\section{Moderating Role of Organizational Learning Culture}

Organizational learning culture is a source of competitive advantage for most of the organizations as it increases job commitment, and level of satisfaction Aycan et al. (1999). In addition to that Pettigrew (1979), states that an employee makes decisions in an organization culture that affects the performance of an organization. The findings of Ogbonna and Harris (2000) indicates a positive relationship between organizational learning culture and the performance of an organization. In addition to that Shahzad et al. (2013), reveals that organizational learning culture can be used as a key for performance excellence and in the productivity of an organization. Whereas, according to Kozlowski and Klein (2000), organizational culture must be based on true values in order to have high productivity and growth.

H3: Organizational Learning Culture moderates between effective communication and employee's performance.

H4: Organizational Learning Culture moderates between work environment and employee's performance.

\section{Conceptual Framework}

This portion highlighted the relationship between effective communication and work environment and the influence of effective communication and job environment on the performance of employees through the moderating role of organizational learning culture. In addition to that hypothesis were made on the basis of literature and framework which helps to assess the relationship of these variables.

\section{Research Framework}

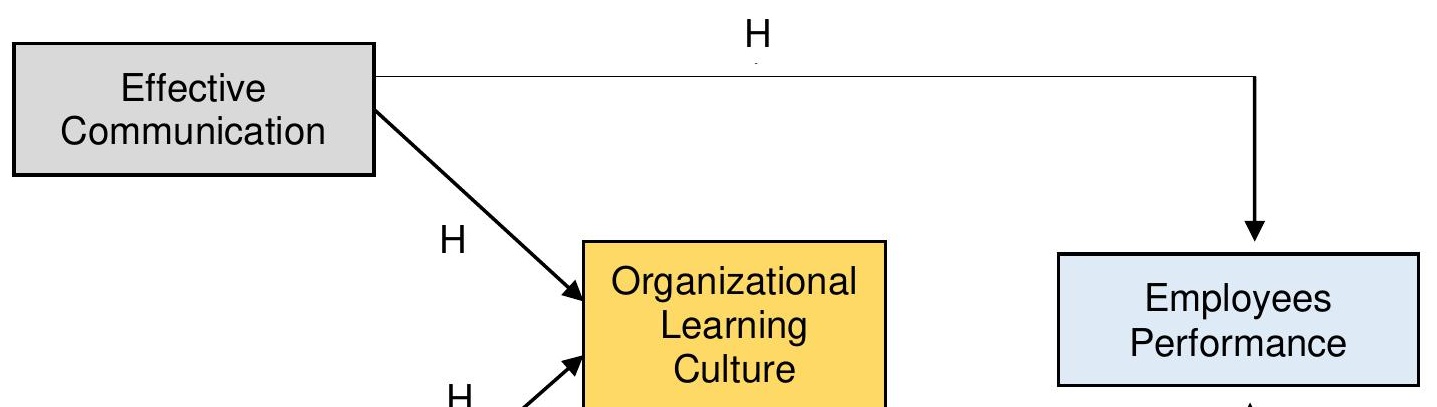


Figure 1: Research Framework

\section{Research Methodology}

This research has been conducted to examine the influence of effective communication and work environment on employee's performance. For the said purpose, effective communication and work environment has been used as an independent variable whereas organizational performance has been used as a dependent variable. The sample population was the employees of FMCG sector of Punjab region. Creswell (2009) states that the population used by the researcher to explore some phenomenon is known as selected population. A number of 215 questionnaires were circulated through online google forms for the purpose of data collection. In order to save time and budget a sample has been made drawn from the population. Primary and secondary data was used for this study. Convenient sampling has been used in this research. The collected data was analyzed by using Statistical package for Social Science SPSS. Pearson correlation and regression analysis, ANOVA, Cronbach's Alpha was performed in order to reveal the influence of effective communication and work environment on employee's performance.

\section{Result \& Discussion}

In this chapter the analysis of collected data was performed. The study used qualitative approach to collect data from FMCG sector of Punjab, Pakistan. Descriptive analysis was performed to analyze frequency of demographic segment i.e. age, gender. After this, confirmatory factor analysis was done through KMO and Bartlett's test of sphericity. Then the reliability of factor is assessed by reliability test. Further Pearson correlation and Regression analysis was performed to examine the impact and relationship among variables. In the last step, PLS regression was used to find the significance and relationship between effective communication, working environment and employee performance with moderating role of training \& development. Below is the detail of the results obtained:

\section{Demographic study}

A total number of 215 questionnaire were circulated and the response rate was $100 \%$., sample participants were aged between 25 years to 50 years comprising 57\% males and $42 \%$ females. (See Table 5.2). This information has been compiled through descriptive statistics which highlights the information about gender and age of the participants.

Table 5.1: Statistical Analysis of Participant's Demographic Study

\begin{tabular}{|l|l|l|l|l|}
\hline \multicolumn{2}{|l|}{} & Gender & Status of Employment & Age \\
\hline $\mathrm{N}$ & Valid & 215 & 215 & 215 \\
\cline { 2 - 5 } & Missing & 0 & 0 & 0 \\
\hline Mean & .5748 & 1.6075 & 2.3505 \\
\hline Std. Error of Mean & .03387 & .05110 & .05060 \\
\hline Median & 1.0000 & 1.0000 & 2.0000 \\
\hline Mode & 1.00 & 1.00 & 2.00 \\
\hline Std. Deviation & .49554 & .74754 & .74024 \\
\hline Variance & .246 & .559 & .548 \\
\hline Skewness & -.305 & .920 & .807 \\
\hline Std. Error of Skewness & .166 & .166 & .166 \\
\hline Kurtosis & -1.925 & -.132 & .703 \\
\hline
\end{tabular}




\begin{tabular}{|l|l|l|l|}
\hline Std. Error of Kurtosis & .331 & .331 & .331 \\
\hline Minimum & .00 & 1.00 & 1.00 \\
\hline Maximum & 1.00 & 4.00 & 5.00 \\
\hline Sum & 123.00 & 344.00 & 503.00 \\
\hline
\end{tabular}

\section{Gender}

In this study there were both male and female respondents. About one hundred and twenty three or $57 \%$ of the respondents were male whereas ninety two or 42 percent of the respondents were female.

Table 5.2: Frequency distribution of the gender

\begin{tabular}{|l|l|l|l|l|l|}
\hline \multicolumn{2}{|c|}{} & Frequency & Percent & Valid Percent & Cumulative Percent \\
\hline \multirow{3}{*}{ Valid } & Female & 91 & 42.5 & 42.5 & 42.5 \\
\cline { 2 - 6 } & Male & 123 & 57.5 & 57.5 & 100.0 \\
\cline { 2 - 6 } & Total & 214 & 100.0 & 100.0 & \\
\hline
\end{tabular}

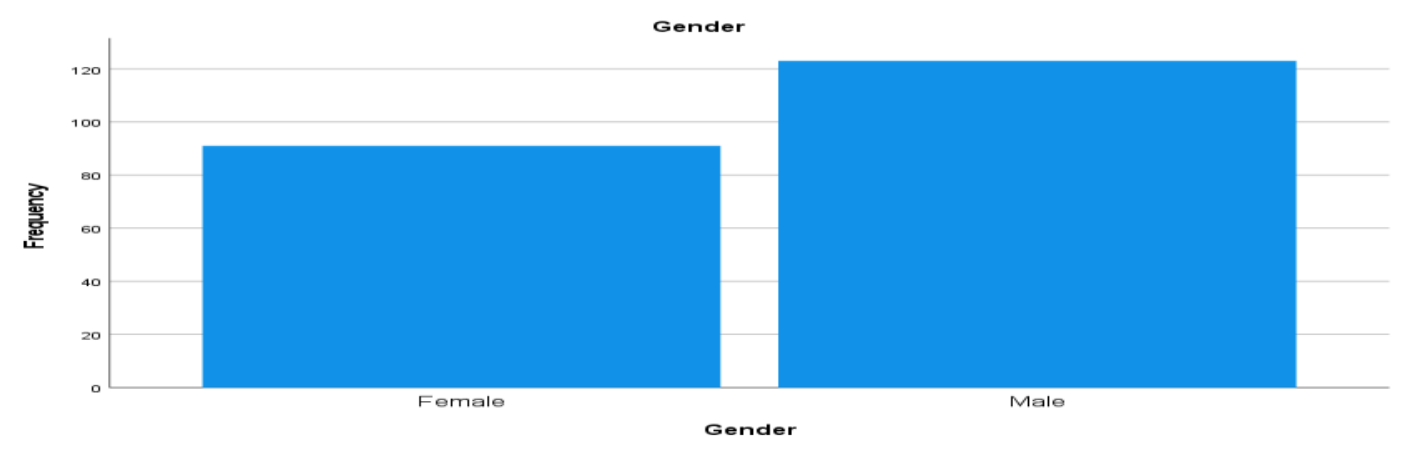

Fig 5.1: Graphical Representation of Gender of the participants

\section{Age of the Participants}

Below mentioned frequency analysis shows the age of the participants which lies from twenty five to fifty years. Out of which six percent were under the age 25-30 years, sixty percent were under the age of 30-35, twenty four percent were under the age of 35-40, seven percent were under 40-45 and point five percent was under 45-50 years.

Table 5.3. Age of the Participants

\begin{tabular}{|l|l|l|l|l|l|}
\hline \multicolumn{2}{|l|}{ Age } & Frequency & Percent & Valid Percent & Cumulative Percent \\
\hline \multirow{4}{*}{ Valid } & $25-30$ & 14 & 6.5 & 6.5 & 6.5 \\
\cline { 2 - 7 } & $30-35$ & 130 & 60.7 & 60.7 & 67.3 \\
\cline { 2 - 6 } & $35-40$ & 52 & 24.3 & 24.3 & 91.6 \\
\cline { 2 - 6 } & $40-45$ & 17 & 7.9 & 7.9 & 99.5 \\
\cline { 2 - 6 } & $45-50$ & 1 & .5 & .5 & 100.0 \\
\cline { 2 - 6 } & Total & 214 & 100.0 & 100.0 & \\
\hline
\end{tabular}


Fig. 5.2: Graphical representation of age of the participants

\section{Confirmatory Factor Analysis}

Confirmatory factor analysis (CFA) is a statistical technique that has been used by most of the researchers. CFA focuses on modeling the relationship between manifest (i.e., observed) indicators and underlying latent variables (factors).

\section{KMO \& Bartlett's Test of Sphericity}

KMO \& Bartlett's Test of Sphericity is one of the aspect of confirmatory factor analysis. This test is used to check the adequacy level of sampling and the case to variable ratio of the analysis. The accepted index of KMO is over 0.6.

Table 5.6. KMO \& Bartlett's Test of Sphericity

\begin{tabular}{|l|l|l|}
\hline KMO and Bartlett's Test & .483 \\
\hline Kaiser-Meyer-Olkin Measure of Sampling Adequacy. & 632.138 \\
\hline \multirow{3}{*}{ Bartlett's Test of Sphericity } & Approx. Chi-Square & 190 \\
\cline { 2 - 3 } & Df & $<.001$ \\
\cline { 2 - 3 } & Sig. & \\
\hline
\end{tabular}

In this study the value of $\mathrm{KMO}$ is greater than 0.6 which means that the selected sample of the study is adequate and is according to the findings of Pallant 2007.

Table 5.7 Total Variance Explained (n=215)

\section{Total Variance Explained}

\begin{tabular}{|c|c|c|c|c|c|c|c|c|c|}
\hline \multirow[b]{2}{*}{$\begin{array}{l}\text { Compone } \\
\mathrm{nt}\end{array}$} & \multicolumn{3}{|c|}{ Initial Eigenvalues } & \multicolumn{3}{|c|}{$\begin{array}{l}\text { Extraction Sums of Squared } \\
\text { Loadings }\end{array}$} & \multicolumn{3}{|c|}{$\begin{array}{l}\text { Rotation Sums of Squared } \\
\text { Loadings }\end{array}$} \\
\hline & Total & $\begin{array}{l}\% \text { of } \\
\text { Variance }\end{array}$ & $\begin{array}{l}\text { Cumulative } \\
\%\end{array}$ & Total & $\begin{array}{l}\% \text { of } \\
\text { Variance }\end{array}$ & $\begin{array}{l}\text { Cumula } \\
\text { tive \% }\end{array}$ & Total & $\begin{array}{l}\% \text { of } \\
\text { Variance }\end{array}$ & $\begin{array}{l}\text { Cumulative } \\
\%\end{array}$ \\
\hline 1 & 1.979 & 9.897 & 9.897 & 1.979 & 9.897 & 9.897 & 1.637 & 8.186 & 8.186 \\
\hline 2 & 1.903 & 9.515 & 19.412 & 1.903 & 9.515 & 19.412 & 1.618 & 8.089 & 16.276 \\
\hline 3 & 1.679 & 8.396 & 27.808 & 1.679 & 8.396 & 27.808 & 1.611 & 8.055 & 24.331 \\
\hline 4 & 1.628 & 8.142 & 35.951 & 1.628 & 8.142 & 35.951 & 1.597 & 7.987 & 32.317 \\
\hline 5 & 1.532 & 7.658 & 43.608 & 1.532 & 7.658 & 43.608 & 1.525 & 7.627 & 39.945 \\
\hline 6 & 1.466 & 7.329 & 50.937 & 1.466 & 7.329 & 50.937 & 1.510 & 7.550 & 47.494 \\
\hline 7 & 1.308 & 6.538 & 57.475 & 1.308 & 6.538 & 57.475 & 1.463 & 7.313 & 54.808 \\
\hline 8 & 1.211 & 6.053 & 63.528 & 1.211 & 6.053 & 63.528 & 1.450 & 7.248 & 62.056 \\
\hline 9 & 1.077 & 5.386 & 68.914 & 1.077 & 5.386 & 68.914 & 1.372 & 6.859 & 68.914 \\
\hline 10 & .922 & 4.608 & 73.523 & & & & & & \\
\hline 11 & .864 & 4.322 & 77.845 & & & & & & \\
\hline 12 & .669 & 3.346 & 81.191 & & & & & & \\
\hline 13 & .614 & 3.070 & 84.260 & & & & & & \\
\hline
\end{tabular}




\begin{tabular}{|l|l|l|l|l|l|l|l|l|l|}
\hline 14 & .586 & 2.928 & 87.189 & & & & & & \\
\hline 15 & .559 & 2.797 & 89.986 & & & & & & \\
\hline 16 & .474 & 2.369 & 92.354 & & & & & & \\
\hline 17 & .446 & 2.230 & 94.585 & & & & & & \\
\hline 18 & .391 & 1.956 & 96.541 & & & & & & \\
\hline 19 & .381 & 1.905 & 98.447 & & & & & & \\
\hline 20 & .311 & 1.553 & 100.000 & & & & & & \\
\hline
\end{tabular}

\section{Reliability Test}

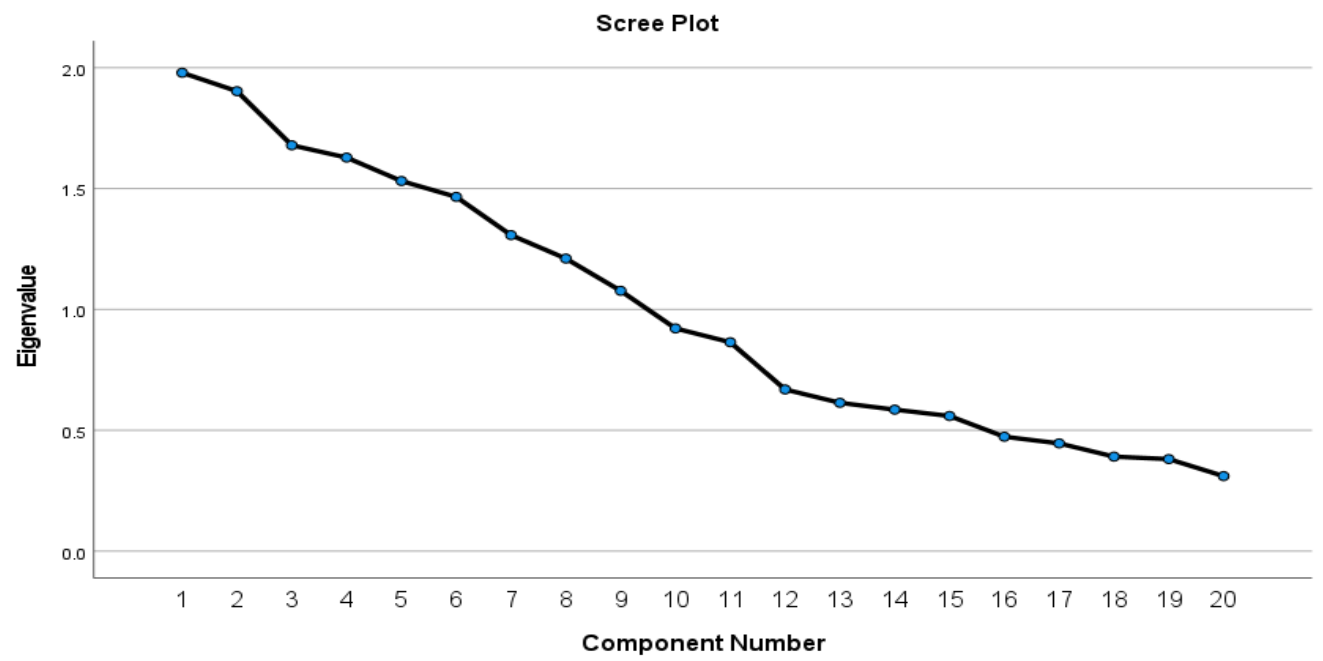

In order to measure the reliability of the factors Cronbach's Alpha test has been conducted. The value of Cronbach's Alpha is greater than 0.7 which indicated the adequacy of the factors in line with the findings of Hair et.al., 2010.

Table 5.9: Reliability Statistics

\begin{tabular}{|l|l|l|}
\hline Reliability Statistics & $\begin{array}{l}\text { Cronbach's Alpha Based on } \\
\text { Standardized Items }\end{array}$ & N of Items \\
\hline Cronbach's Alpha & .684 & 24 \\
\hline .764 & & \\
\hline
\end{tabular}

\section{Pearson Correlation}

The relationship between Effective Communication, Working environment, and Employee Performance with moderating role of Organizational culture was assessed through Pearson Correlation in SPSS27. The results of the Pearson Correlation analysis indicates a positive relationship among these variables.

\begin{tabular}{|c|c|c|c|c|c|}
\hline \multicolumn{6}{|c|}{ Correlations } \\
\hline & & Total_EC & Total_WE & Total_EP & Total_OC \\
\hline \multirow[t]{3}{*}{ Total_EC } & Pearson Correlation & 1 & $.244^{* * *}$ & $.194^{* *}$ & $.239^{* *}$ \\
\hline & Sig. (2-tailed) & & $<.001$ & .000 & $<.001$ \\
\hline & $\mathrm{N}$ & 214 & 213 & 212 & 210 \\
\hline \multirow{3}{*}{ Total_WE } & Pearson Correlation & $.244^{* *}$ & 1 & $.223^{* *}$ & $.224^{* *}$ \\
\hline & Sig. (2-tailed) & $<.001$ & & .001 & .001 \\
\hline & $\mathrm{N}$ & 213 & 214 & 212 & 209 \\
\hline \multirow[t]{3}{*}{ Total_EP } & Pearson Correlation & $.194^{* * *}$ & $.223^{* *}$ & 1 & $.205^{* *}$ \\
\hline & Sig. (2-tailed) & .005 & .001 & & .003 \\
\hline & $\mathrm{N}$ & 212 & 212 & 213 & 208 \\
\hline
\end{tabular}




\begin{tabular}{|l|l|l|l|l|l|}
\hline \multirow{3}{*}{ Total_OC } & Pearson Correlation & $.239^{* *}$ & $.224^{* *}$ & $.205^{* *}$ & 1 \\
\cline { 2 - 6 } & Sig. (2-tailed) & $<.001$ & .001 & .003 & \\
\cline { 2 - 6 } & $\mathrm{N}$ & 210 & 209 & 208 & 210 \\
\hline
\end{tabular}

\section{Regression Analysis}

Regression analysis was performed to analyze the impact of Effective Communication, Working environment on Employee Performance with moderating role of Organizational culture. However, regression analysis confirms that there is a positive and significant relationship between these variables.

\begin{tabular}{|l|l|l|l|l|}
\hline Model Summary & \multicolumn{3}{l|}{} \\
\hline Model & R & R Square & Adjusted R Square & Std. Error of the Estimate \\
\hline 1 & $.302^{\mathrm{a}}$ & .091 & .078 & .85568 \\
\hline a. Predictors: (Constant), Total_OC, Total_WE, Total_EC \\
\hline
\end{tabular}

Table 5.12: ANOVA ${ }^{\mathrm{b}} \mathrm{s}$

\begin{tabular}{|l|l|l|l|l|l|l|}
\hline ANOVA $^{\text {a }}$ & Sum of Squares & df & Mean Square & F & Sig. \\
\hline Model & Regression & 14.882 & 3 & 4.961 & 6.775 & $.001^{\text {b }}$ \\
\cline { 2 - 7 } & Residual & 148.635 & 203 & .732 & & \\
\cline { 2 - 6 } & Total & 163.517 & 206 & & & \\
\hline
\end{tabular}

Table 5.13: Coefficients ${ }^{\mathrm{a}}$

\begin{tabular}{|c|c|c|c|c|c|c|}
\hline & $n^{2} s^{a}$ & & & & & \\
\hline & & Unstal & oefficients & $\begin{array}{l}\text { Standardized } \\
\text { Coefficients }\end{array}$ & & \\
\hline & & $\mathrm{B}$ & Std. Error & Beta & $\mathrm{t}$ & Sig. \\
\hline 1 & (Constant) & 0.596 & .788 & & 6.835 & .001 \\
\hline & Total_EC & .134 & .081 & .116 & 1.647 & .001 \\
\hline & Total_WE & .164 & .066 & .174 & 2.477 & .014 \\
\hline & Total_OC & .134 & .067 & .140 & 2.004 & .046 \\
\hline
\end{tabular}

Hence, the above mentioned analysis shows a positive impact of Effective Communication, Working environment, and Employee Performance with moderating role of Organizational culture. The value of slope coefficient if 0.116 ; the value of $t$ is 2.835 which indicates a positive relationship between Effective Communication, Working environment, and Employee Performance with moderating role of Organizational culture. On the other hand, the value of coefficient is 0.596 ; the value of $t$ is 6.835 .

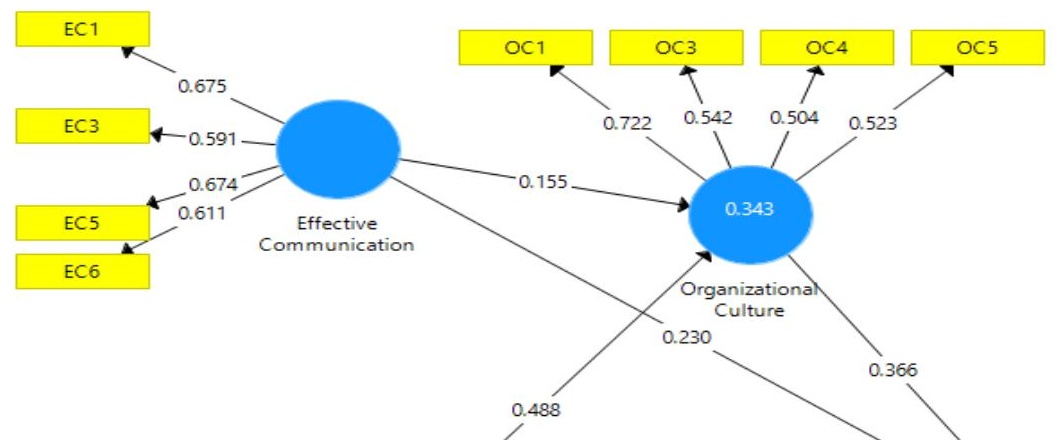


Fig. 5.5: Measurement model

\begin{tabular}{|c|c|c|c|c|c|c|c|}
\hline Variables & $\begin{array}{l}\text { Coded } \\
\text { Items }\end{array}$ & $\begin{array}{l}\text { Outer } \\
\text { Loadings }\end{array}$ & AVE & $\begin{array}{l}\text { Composite } \\
\text { Reliability }\end{array}$ & $\begin{array}{l}\text { R } \\
\text { Square }\end{array}$ & $\begin{array}{l}\text { Cronbach's } \\
\text { Alpha }\end{array}$ & $\begin{array}{l}\text { Commu } \\
\text { nality }\end{array}$ \\
\hline \multirow{4}{*}{$\begin{array}{l}\text { Effective } \\
\text { Communication }\end{array}$} & EC1 & 0.675 & 0.653 & 0.741 & & 0.633 & 0.682 \\
\hline & EC3 & 0.591 & & & & & \\
\hline & EC5 & 0.674 & & & & & \\
\hline & EC6 & 0.611 & & & & & \\
\hline \multirow{4}{*}{$\begin{array}{l}\text { Working } \\
\text { Environment }\end{array}$} & WE3 & 0.622 & 0.720 & 0.702 & & 0.632 & 0.725 \\
\hline & WE4 & 0.568 & & & & & \\
\hline & WE5 & 0.598 & & & & & \\
\hline & WE6 & 0.530 & & & & & \\
\hline \multirow{3}{*}{$\begin{array}{l}\text { Employee } \\
\text { Performance }\end{array}$} & EP 1 & 0.771 & 0.690 & 0.654 & & 0.740 & 0.623 \\
\hline & EP3 & 0.681 & & & & & \\
\hline & EP5 & 0.502 & & & 0.331 & & \\
\hline \multirow{4}{*}{$\begin{array}{l}\text { Organizational } \\
\text { Learning Culture }\end{array}$} & $\mathrm{OC} 1$ & 0.722 & 0.753 & 0.620 & & 0.642 & 0.711 \\
\hline & OC3 & 0.542 & & & & & \\
\hline & $\mathrm{OC} 4$ & 0.504 & & & 0.343 & & \\
\hline & OC5 & 0.523 & & & & & \\
\hline
\end{tabular}

PLS model includes the composite reliability, average variance extracted, Cronbach's Alpha and communality in order to evaluate internal consistency of the variables.

\section{Average Variance Extracted (AVE)}

In this study the AVE of Effective communication was 0.653, Working Environment (0.720), Organizational Learning Culture (0.753) and employee performance was (0.690)

\section{Composite Reliability}

Composite reliability is the measure of internal consistency. According to Hair et al., 2010, the value of reliability coefficient must exceed than 0.70 . However, the values as low as 0.50 are acceptable at initial construct development (Nunnally 1967). In this study the composite reliability was concluded as Effective communication (0.741), Working Environment (0.702), Employee Performance (0.654), Organizational Learning Culture (0.620)

\section{R Square}

In order to evaluate a structural model $\mathrm{R}^{2}$ (coefficient determination) is used. This is used to measure predictive accuracy of the model and is calculated as a squared correlation between actual and observed values. In this study $\mathrm{R}^{2}$ values of Employee Performance was calculated as (0.331) while of Organizational Learning Culture is (0.343). 


\section{Cronbach's Alpha}

According to Hair et.al., 2010, the values more than 0.6 are acceptable. In this study, cronbach alpha is more than 0.6 which clearly indicates that the variables of this study are reliable.

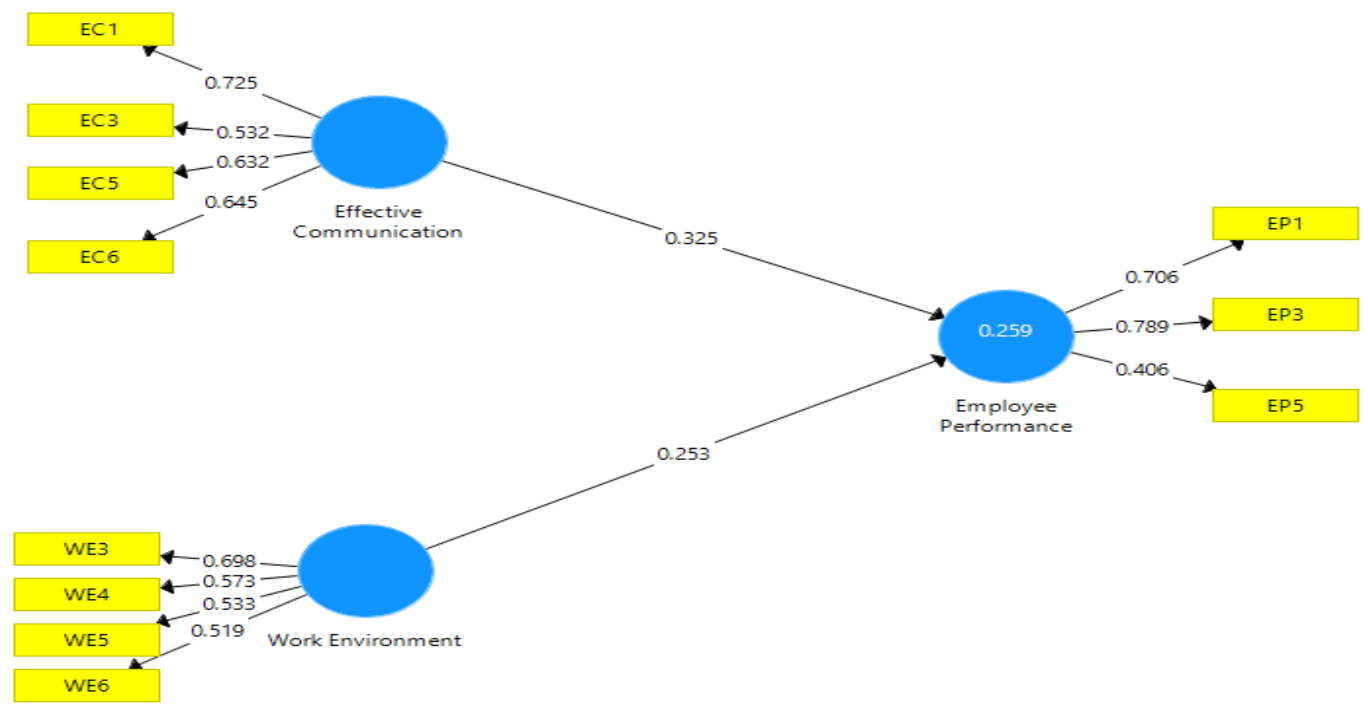

Fig. 5.6: Structural Equation Model (Direct relationships)

\section{Summary of the Results}

In this study the relationship of dependent (employee performance) and independent (effective communication, working environment) variables was examined by the role of moderator (organizational learning culture). For the purpose of data collect a number of two hundred and fifteen employees was selected from FMCG sector of Punjab, Pakistan. Analysis of the collected data was performed with the help of statistical package for social sciences. Reliability and validity were tested by using factor analysis and cronbach's alpha. Then the significance was further analyzed by using regression and correlation analysis. The factor analysis confirmed the significance of the variables. The results of cronbach alpha were greater than 0.7 which confirms the reliability of the variables.

In addition to that, correlation analysis confirms that all the variables i.e., effective communication, working environment, organizational culture and employee performance are significant and correlated.

\section{Conclusion}

In this part, the findings and results of previous areas are discussed. Further suggestions are also given on the basis of previous chapters and results. In the last section of this chapter further research for future researchers is discussed which gives suggestions to future researchers for further research.

On the basis of interpretations, results and discussions it has been concluded that:

1. Effective communication helps to increase the performance of an organization, improve employee's coordination, productivity and ultimately helps to increase the performance of a particular sector (Obeidat et al., 2018).

2. Effective communication helps to build confidence level of employees whereas weak communication losses the confidence of employees. Therefore, effective communication has an impact on the performance of employees.

3. Working environment helps to share knowledge and information informally in an organization in order to enhance mutual coordination and increasing productivity. The 
ability to share knowledge in an organization depends upon the work environment of that organization (Brenner (2004).

4. Such environment by allowing free flow of effective communication can be used as a tool to motivate employees for producing better results. In the views of Mokaya et al. (2013) working environment plays an important role in order to increase job satisfaction of employees.

5. Organizational learning culture is a source of competitive advantage for most of the organizations as it increase job commitment, and level of satisfaction Aycan et al. (1999).

6. An employee makes decisions in an organization culture that affects the performance of an organization Pettigrew (1979). That's why working environment had a direct impact on the performance of employees.

7. In a nutshell, effective communication, working environment, is of utmost importance for FMCG sector. This works in the best interest of an employee and an institution. An employee gets comfortable environment and get innovative ideas and more knowledge through effective communication an institution performs well and achieve organizational objectives which leads higher institutions towards more output and success.

\section{Future Recommendations}

On the basis of above mentioned results the management of FMCG sector of Punjab, Pakistan is suggested to use effective communication technique and make sure the provision of more comfortable working environment through organizational learning culture to employees in order to enhance productivity.

The present study reveals that effective communication and working environment plays an important role in FMCG sector of Punjab, Pakistan. It suggests that the performance of employees can be increased by providing comfortable working environment and treating them in a more effective way. By following below mentioned ways FMCG sector can enhance employee's performance.

Firstly, management of this sector must set some standards and policies to behave in a certain way within an organization and with the customers simultaneously. In this way employees communicate with each other and with customers effectively.

Secondly, managers must interact with the subordinates on weekly or monthly basis in the form of meetings or seminars for the purpose of communicating the pros and corns of effective communication and working environment. This will help this sector to adopt changes in their present ways of dealing with each other.

Finally, by setting rules and policies and by providing awareness to employees FMCG sector would be in a position to use effective communication and improve their working environment by having organizational learning culture in this sector.

\section{Limitations of the research}

Shortage of time is the limitations of this research. Further, this research has been conducted in Punjab. More research can be done in throughout the world. This research has used FMCG sector specifically to examine the impact of effective communication hence, further research can be done by using other sectors i.e. Education, Agriculture, IT etc.

In addition to that this study is based on the impact of effective communication and working environment on the employee's performance through the moderating role of organizational culture further research can be made on the ways or methods improve working conditions of this sector.

\section{References}


A. Khan, S. (2005). How to Motivate Good Performance among Government employees. Pakistan Journal of Social Sciences, 3(9), 1138-1143.

Abbas, Q. and Yaqoob, S. (2009) Effect of leadership development on employee performance in Pakistan, Pakistan Economic and Social Review, Vol. 47, pp. 269-292.

Adeoti J. A. and Isiaka S.B., 2006. Non-financial Compensation and its Impacts on Employee Performance in Selected Nigerian Firms, Ilorin Journal of Business and Social Sciences, Published by the Faculty of Business and Social sciences, University of Ilorin, Ilorin, 11(1 \& 2): 3-11.

Ahmad, A. Kausar, A. R. \& Sharif, M.Y. (2012). Preliminary study of the moderating effect of organizational support on the relationship between HR competencies, HR willingness and HR professionals' Effectiveness Link: A study of line manager in a Pakistani banking sector. 2nd International Conference on Business Management (pp. 1-24), Lahore, Pakistan

Allen, T. D. (2001). Family-Supportive Work Environments: The Role of Organizational Perceptions. Journal of Vocational Behavior, 435, 414-435.

Amah, E (2009) Corporate Culture and Organizational Effectiveness. A Study of the Nigerian Banking Industry. An Unpublished PhD Thesis of the Faculty of Management Sciences, University of Port Harcourt, Nigeria. Armstrong M. (2011)

Amir, F. (2010).Measuring the impact of office environment on performance level of employees. Global Environment. Bhurban, Pakistan appraisal. Glenview: Scott, Foresman and Company.

Armstrong's handbook of human resource management practice, London, Kogan Page.

Barney, J.B. (1991). Firm Resources and Sustained Competitive Advantage. Journal of Management,1 (17): 99-120

Baron, R. A., 1994. The physical environment of work settings: Effects on task performance, interpersonal relations, and job satisfaction, Research in OBehavior (Vol. 16, pp. 1-46). Greenwich, CT: JAI Press.Book Review: Creswell, J.,\& Plano Clark,V.(2007). Designing and Conducting Mixed Methods Research. Thousand Oaks, CA: Sage.

Bernstein, E. S. (2017). Making transparency transparent: The evolution of observation in management theory. Academy of Management Annals, 11(1), 217-266.

Brooks, I. (2006). Organizational Behaviour: Individuals, Groups and Organization. Essex: Pearson Education Limited.

Cascio, W. F. (2006). Managing Human Resources: Productivity, Quality of Life, Profits. McGraw-Hill

Chandrasekar, K. (2011) "Workplace environment and its impact on organisational performance in public sector organisations." International Journal of Enterprise Computing and Business Systems 1.1, 1-16

Davis, T. R. V., 1984. The influence of the physical environment in offices. Academy of Management Review, 9(2), 271-283.

Deal, T.E. \& Kennedy, A.A., 1982. Corporate Cultures.The Rites and Rituals of Corporate Life. Addison-Wesley, Reading, MA

Franco LM, Bennett S, Kanfer R,\& Stubblebine P, (2000).Health Worker Motivation in Jordan and Georgia: A Synthesis of the Results, Major Applied Research 5, Technical Paper 3 Bethesda, Maryland: Partnership for Health Reform Project.

Fuertes, G., Alfaro, M., Vargas, M., Gutierrez, S., Ternero, R., \& Sabattin, J. (2020). Conceptual Framework for the Strategic Management: A Literature Review-Descriptive. Journal of Engineering, 2020.

Gamble, P. R., \& Gibson, D. A., 1999. Executive values and decision-making: The relationship of culture and information flows. Journal of Management Studies, 36, 217-240.

Jiang, X., Du, J., Zhou, J., \& Cui, Y. (2020). The Impact of Negative Informal Information Before a Change on Performance: A WithinPerson Approach. International Journal of Environmental Research and Public Health, 17(2), 670 
Odine, M. (2015). "Impact of working environment on employee's productivity: A case study of Banks and Insurance Companies in Pakistan." European Journal of Business and Management 7(1): 329- 345

Rukmana, H. D., MM, S. M. P., \& SE, E. N. (2018). The Impact of Organization Communication on Employee Performance Through Employee's Work Motivation at Pt. Putri Panda Unit Ii Tulungagung, East Jawa, Indonesia. KnE Social Sciences, 211-227.

Sarode, P. A. and Shirsath, M., (2014) "The Factors Affecting Employee Work Environment \& It's Relation with Employee Productivity." International Journal of Science and Research (IJSR), 3(11): 2735-2737.

The Impact of Office Environments on Employees Performance. Journal of Facilities Management, Vol-1 (3), 247-264.

Tian, H., Shuja Iqbal, S. A., Qalati, S. A., Anwar, F., \& Khan, M. A. S. (2020). The Impact of Transformational Leadership on Employee Retention: Mediation and Moderation Through Organizational Citizenship Behavior and Communication. Frontiers in Psychology, 11

Work Environment and its impact on Employees Performance: A study on women employees in BSNL. 